\title{
THE STERILIZATION OF DRESSINGS
}

\author{
BY \\ V. G. ALDER and W. A. GILLESPIE \\ From the Department of Pathology, Bristol Royal Infirmary
}

(RECEIVED FOR PUBLICATION MAY 2, 1957)

The application of moist heat in an autoclave is the best method of sterilizing dressings. In order to kill the most resistant pathogenic spores they must be exposed for at least 20 minutes to saturated steam at $121^{\circ} \mathrm{C}$. (Ministry of Health, 1955). At this temperature pure steam exerts a pressure of $15 \mathrm{lb}$./sq. in. The steam should be dry but at the phase boundary between liquid and vapour, so that it condenses readily and transfers its latent heat to cooler objects.

The efficient removal of air from the autoclave chamber and its contents is essential for satisfactory sterilization. Air trapped inside dressings may hinder penetration by steam, and also may cause, temporarily, a condition of unsaturation (Savage, 1937). Unsaturation may also be caused in other ways, for example, by allowing the temperature of the autoclave jacket to rise much above that of the chamber.

Air may be removed from the chamber and its contents before sterilization either by forced evacuation or by downward displacement. Evacuation is usually carried out by means of a steam ejector which creates a partial vacuum of 15 to $20 \mathrm{in}$. $\mathrm{Hg}$, once or twice, the air being replaced each time by steam. A more efficientand more costly-pump can be employed to give a partial vacuum of 26 to 28 in. $\mathrm{Hg}$. In the downward displacement method the air, being heavier than steam, gravitates to the bottom of the chamber and thence escapes through a vent. A thermometer in the escape line shows when the steam in the bottom of the chamber is free from air, since the presence of air reduces the temperature below that of pure steam at the operating pressure.

Evacuation cannot remove all the air from a mass of dressings, since the vacuum is not complete. Even if the evacuation is repeated, there will still be residual air which may be compressed finally by the steam to a position at the centre of the mass (Savage, 1937). Downward displacement is preferred by some authorities (Walter, 1948; Bowie, 1955), but, as Walter points out, its efficiency must depend in part on the method of pack- ing and loading the dressings. The authors have felt that reliance on the thermometer in the steam escape line to show that the dressings are free from air might lead to error, since air might escape so slowly from the dressings that the thermometer would not be sensitive enough to detect its presence. This possibility would be greater if the dressings were badly packed and the packages or drums few. For the commercial sterilization of dressings Perkins (1956) states that an efficient pump, capable of evacuating up to 26 to $28 \mathrm{in}$. $\mathrm{Hg}$, provides the best means of removing air. Some manufacturers of autoclaves recommend a combined method consisting of double evacuation up to 18 to $20 \mathrm{in}$. $\mathrm{Hg}$, followed by continuous venting during sterilization.

The use of metal drums to hold dressings, towels, etc., is open to criticism. Heat penetration is slower than in fabric-wrapped packages (Walter, 1948). The use of drums encourages overpacking (Howie and Timbury, 1956).

Although a good deal has been written about methods of autoclaving dressings, comparatively little has been done to evaluate them experimentally. In particular, there is a lack of evidence to support some of the statements which have been made about the merits of different ways of removing air. In the work reported here residual air trapped inside dressings has been measured and temperatures recorded at points inside the autoclave and its contents, and the efficiency of sterilization has been assessed under various conditions by means of heat-resistant spores and chemical tests. The objects were to compare the efficiency of sterilization after the removal of air by double evacuation with that by downward displacement, to compare drums with packages, and chemical with bacteriological tests of sterilization.

\section{MATERIALS AND METHODS}

A horizontal cylindrical jacketed autoclave, by James Slater \& Co., of 28 cubic feet capacity, was used for most of the experiments. Steam was admitted through a "rose" opening placed slightly to one 
side of the top of the chamber, near the front. The autoclave was fitted with an ejector connected to the bottom of the chamber for creating a vacuum of 20 in. $\mathrm{Hg}$ and a condensate discharge tube whose opening, also from the bottom of the chamber, was controlled by a screw hand valve. The working pressures in jacket and chamber were 25 and $20 \mathrm{lb}$. per sq. in. respectively, both being controlled by spring-loaded safety valves. Also some experiments were done with a Manlove Elliott autoclave of similar design.

\section{Methods of Sterilization}

Double Vacuum Method.-Air was removed by double evacuation according to the makers' instructions. With a steam pressure of $25 \mathrm{lb}$./sq. in. in the jacket, a partial vacuum of $20 \mathrm{in}$. $\mathbf{H g}$ was drawn in the chamber. Steam was then admitted to a pressure of $20 \mathrm{lb}$., and the discharge valve opened to allow condensate to escape and then closed. The evacuation was repeated and steam readmitted as before. The condensate discharge valve was then opened enough to allow steam to escape briskly throughout the ensuing sterilization period, but without lowering the chamber pressure, which stayed at $20 \mathrm{lb} . / \mathrm{sq}$. in. Although standard practice here is to sterilize drums for 30 minutes, in these experiments shorter periods were sometimes used in order to give marginal conditions.

Downward Displacement Method.-Steam was admitted to the jacket at $25 \mathrm{lb}$./sq. in., and then to the chamber. The condensate discharge valve was kept open enough to give a brisk escape of steam while allowing the chamber pressure to reach and stay at $20 \mathrm{lb}$./sq. in The temperature in the discharge line was recorded by a thermistor (see below) placed just beyond its opening from the chamber. After the instrument had reached a stable temperature of $126^{\circ} \mathrm{C}$. (the temperature of pure steam at $20 \mathrm{lb}$. $/ \mathrm{sq}$. in.), the chamber pressure remained constant throughout the sterilization period, during which steam flowed briskly from the discharge valve. The duration of sterilization was varied as with the vacuum method.

\section{Drums and Towels}

Cylindrical metal drums with perforated sides were used. They were 12 in. in diameter, 9 in. deep and of about 17 litres capacity.

The drums were loaded with folded "huckaback" towels, 38 in. $\times 20$ in. For most experiments, 18 folded towels were placed in a drum lined with two

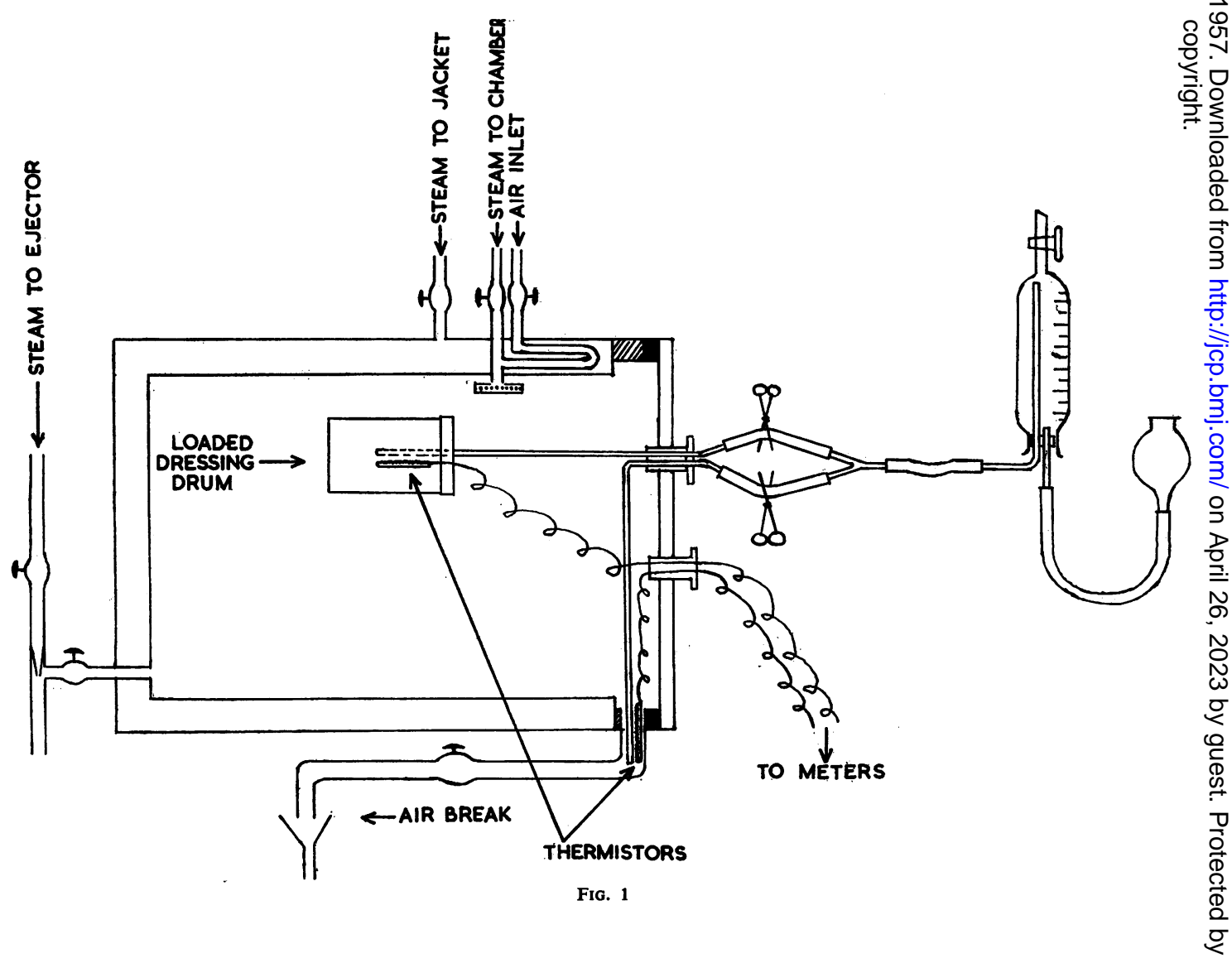


layers of muslin, giving packing which, although fuller than would be allowed in practice, was not tight enough to prevent the towels from falling out if the drum was inverted. The orientation of the folds was varied in different experiments. When tightly packed drums were required 23 towels were used. The drums were usually placed in the upper part of the chamber.

\section{Measurement of Trapped Air}

Samples of the atmosphere inside the chamber, drums, or packages were collected by means of two flexible copper tubes $1 / 16$ in. bore and about $3 \frac{1}{2} \mathrm{ft}$. long. The tubes were passed through a gland screwed into the door of the autoclave. The outer ends of the tubes were connected by rubber pressure tubing, clamped by artery forceps, to a Y-piece leading to an inverted graduated separating funnel $(250 \mathrm{ml}$. capacity) as shown in Fig. 1. The funnel and tubing back to the clamps were filled with mercury. Special care was taken to ensure that all junctions were airtight.

To measure trapped air, the reservoir was lowered to create a negative pressure, and, with the autoclave at full pressure, the appropriate clamp was released for three seconds. When the apparatus had cooled and steam had condensed, the mercury levels were equalized and the volume of air in the funnel was measured. After ejecting the air and water from the funnel, the procedure was repeated until less than $5 \mathrm{ml}$. of air could be collected in three seconds. When the volume of trapped air was large, up to 10 such collections were required. The total volume of air discharged through the tube was then determined. The period of three seconds was chosen because, when the amount of trapped air was large, the funnel sometimes just filled in that time.

\section{Measurement of Temperature}

Temperatures in drums and discharge line were measured by means of "stantel" thermistors (type F/1512/300) which had previously been calibrated in hot oil against a mercury thermometer. Between $90^{\circ}$ and $130^{\circ} \mathrm{C}$. there was a linear relationship between the temperature and the log milliammeter deflection. Within this range the instrument accurately measured differences of $1^{\circ} \mathrm{C}$. The exposed soldered joints between a thermistor and its insulated leads were separately wrapped with a thread of glass and plastic fibre from a "glassona" bandage and then embedded in "bakelite" polyester resin S.R.17451 in a mould. The resin was polymerized by heating at $45^{\circ} \mathrm{C}$. overnight.

The leads to the recording circuit were passed through a gland in the door of the autoclave, or simply between the door and its gasket.

\section{Bacteriological Tests}

Test papers were prepared as follows: A stock spore suspension of B. stearothermophilus (N.C.A.1518) was heated in an oil bath at $115^{\circ} \mathrm{C}$. for 15 minutes and poured over three slopes in $1 \mathrm{oz}$. screw-capped bottles. The medium consisted of $1 \%$ " bacto" tryptone with $0.3 \%$ " oxoid" lab. lemco and $2.5 \%$ agar, at $p H$ 7.0. The slopes were incubated for four days at $56^{\circ} \mathrm{C}$. The growth was washed off with $2 \mathrm{ml}$. sterile tap water, and shaken. This spore suspension was used to impregnate filter paper strips which were dried and placed in 2 in. $\times \frac{3}{8}$ in. plugged test tubes. Tubes placed in drums and packages were tested for survival after autoclaving by adding $1 \mathrm{ml}$. amounts of tryptone dextrose broth ("oxoid") and incubating at $56^{\circ} \mathrm{C}$. for two days.

The spores were sterilized by saturated steam at $121^{\circ} \mathrm{C}$. in 20 minutes but not in 10 minutes. At $126^{\circ} \mathrm{C}$. they were sterilized in 10 minutes but not in five minutes when tested in an oil bath.*

\section{Chemical Tests}

Type 1 sterilizer control tubes were used, as supplied by Messrs. Albert Browne (Leicester) for checking the sterilization of surgical dressings, etc. They contained a red fluid which became green when heated at $115^{\circ} \mathrm{C}$ for 25 minutes or at $126^{\circ}$ for 13 minutes in an oil bath.

In most experiments, the bacteriological and chemical tests were used side by side, held together by means of strapping.

\section{RESULTS}

\section{Comparison of Downward Displacement and Double Vacuum Methods of Removing Air}

Air in Chamber.-After removal of air, samples from the bottom of the chamber were usually collected in parallel with the samples from drums and packages described below. The chamber atmosphere always contained negligible quantities of air, too small to measure, but less than $5 \mathrm{ml}$. in a three-second sample. As far as could be judged the amounts of air were the same with both methods. Similar traces of air were found in steam from an empty autoclave, and probably came from the steam supply.

Air in Drums.- The amounts of air which could be obtained from the centres of drums after removing air from the chamber by each method were compared on several occasions. Two drums were used in most experiments. On each occasion, air was withdrawn from the chamber by one method, and the residual air trapped in the drums was collected and measured; the chamber was refilled with air and the door opened for about 30 minutes. The procedure was then repeated with the other method without changing the position of instruments or drums. The order

* Further experience has shown that better crops of spores may be obtained by supplying more air to the sporing cultures of $B$. stearothermophilus on a larger surface and by incubating for a longer stearothermophilus on a larger surface and by incubating for a longer
period. The agar medium may be solidified flat, in $50 \mathrm{ml}$. amounts, period. The agar medium may be solidified flat, in $50 \mathrm{ml}$. amounts, $56^{\circ}$ to $60^{\circ} \mathrm{C}$. for seven days. 
was reversed from time to time so that each method came first in about half the experiments. This precaution was taken to allow for the possible effect of moisture, remaining from the first run, on the volume of air trapped during the second. The drums were sometimes placed upright and sometimes on their sides, but the folds of the towels were always vertical.

Neither method of withdrawing air from the chamber removed all the air from the drums (Table I). The double vacuum method was slightly better than the gravity method; the

TABLE I

VOLUMES OF RESIDUAL AIR OBTAINED FROM LOADED DRUMS AND PACKAGES AFTER REMOVING AIR FROM THE CHAMBER BY DOUBLE VACUUM AND DOWNWARD DISPLACEMENT METHODS

\begin{tabular}{|c|c|c|c|c|c|c|}
\hline \multirow{4}{*}{$\begin{array}{l}\text { Expt. } \\
\text { No. }\end{array}$} & \multirow{4}{*}{ Load } & \multirow{4}{*}{$\begin{array}{c}\text { Position } \\
\text { of } \\
\text { Drums } \\
\text { and } \\
\text { Packages }\end{array}$} & \multicolumn{4}{|c|}{$\begin{array}{c}\text { Methods of Air Removal and } \\
\text { Order of Testing }\end{array}$} \\
\hline & & & 1st & 2nd & 1st & 2nd \\
\hline & & & $\begin{array}{c}\text { Down- } \\
\text { ward } \\
\text { Displace } \\
\text { ment }\end{array}$ & $\begin{array}{l}\text { Double } \\
\text { Vacuum }\end{array}$ & $\begin{array}{l}\text { Double } \\
\text { Vacuum }\end{array}$ & $\begin{array}{c}\text { Down- } \\
\text { ward } \\
\text { Displace } \\
\text { ment }\end{array}$ \\
\hline & & & \multicolumn{4}{|c|}{ Volumes of Residual Air (ml.) } \\
\hline 1 & $\begin{array}{l}18 \text { towels in } \\
\text { muslin- } \\
\text { lined drum }\end{array}$ & Upright & - & - & 125 & 265 \\
\hline 2 & $\begin{array}{lll}18 & , \\
18 & ,\end{array}$ &, & 265 & 110 & 145 & 305 \\
\hline \multirow[t]{2}{*}{3} & $\begin{array}{lll}18 & \prime \prime \\
18 & , & ,\end{array}$ & $"$, & 320 & $\begin{array}{l}140 \\
165\end{array}$ & $=$ & 二 \\
\hline & $\begin{array}{rrr}10 & ,, & , \\
9 & ,, & ,\end{array}$ & ,", & 50 & 50 & & \\
\hline 4 & $\begin{array}{lll}23 & , \prime,\end{array}$ & , & 二 & - & $\begin{array}{l}505 \\
200\end{array}$ & $\begin{array}{l}820 \\
240\end{array}$ \\
\hline 5 & $23, "$, & $\begin{array}{l}\text { Onits } \\
\text { side }\end{array}$ & 685 & 265 & - & - \\
\hline 6 & $\begin{array}{l}18, ", ", \\
18 \text { towels in }\end{array}$ & ,", & 145 & 105 & 235 & 260 \\
\hline \multirow[t]{3}{*}{7} & $\begin{array}{l}\text { muslin only } \\
18 \text { towels in } \\
\text { calico-lined }\end{array}$ & , & - & - & 50 & 50 \\
\hline & $\begin{array}{l}\text { drum } \\
18 \text { towels in } \\
\text { muslin- }\end{array}$ & , & - & - & 310 & 370 \\
\hline & $\begin{array}{l}\text { lined drum } \\
18\end{array}$ &,, & 二 & 二 & $\begin{array}{l}205 \\
410\end{array}$ & $\begin{array}{l}195 \\
395\end{array}$ \\
\hline \multirow{2}{*}{$\begin{array}{l}8 \\
9\end{array}$} & $\begin{array}{l}\text { Laparotomy } \\
\mathrm{ki}^{+} \text {, wrapped } \\
\text { in linen } \\
(69 \times 36 \times \\
15 \mathrm{~cm} .)\end{array}$ & - & 365 & 175 & - & - \\
\hline & $\begin{array}{l}\text { Average volum } \\
\text { obtained fron } \\
\text { with } 18 \text { towe }\end{array}$ & $\begin{array}{l}\text { nes of air } \\
\text { n drums } \\
\text { els } \quad .\end{array}$ & 252 & 130 & 233 & 290 \\
\hline
\end{tabular}

difference was greater when the drums were tightly packed or wrongly positioned (see below).

In a few experiments in which the ends of the collecting tubes were placed at different positions in upright drums, most of the air was found to be at the centres of the drums.

Heat Penetration.-On several occasions the temperature during removal of air and steriliza- tion was recorded by means of thermistors placed at the centres of loaded drums. There was no appreciable difference between the temperatures during the sterilization periods. Tight packing of the drums increased the delay in heat penetration, equally with both methods (Fig. 2).

That the delay in heat penetration was due to trapped air was shown by the immediate rise in temperature which followed the opening of an aircollecting tube from the centre of a tightly packed drum during sterilization (Fig. 3).

Bacteriological Tests.-Exposure for 15 minutes to steam at $20 \mathrm{lb}$./sq. in. was sufficient to sterilize all the spore test papers placed near the top, middle, and bottom of drums loaded with 18 towels, irrespective of the method used to remove air. (All the drums were placed on their sides with the folds of the towels vertical so as to facilitate the escape of air.) When the drums were tightly packed with 23 towels or the period of sterilization reduced to 10 minutes, some spores survived (Table II). The number of survivals with

TABLE II

SURVIVAL OF SPORES IN LOADED DRUMS AFTER WITHDRAWAL OF AIR BY DOUBLE VACUUM AND DOWNWARI DISPLACEMENT METHODS

\begin{tabular}{|c|c|c|c|c|c|}
\hline \multirow[b]{2}{*}{$\begin{array}{l}\text { No. of } \\
\text { Drums }\end{array}$} & \multirow[b]{2}{*}{$\begin{array}{c}\text { No. of } \\
\text { Towels } \\
\text { per Drum }\end{array}$} & \multirow{2}{*}{$\begin{array}{c}\text { Steril- } \\
\text { ization } \\
\text { Period } \\
\text { (Minutes) }\end{array}$} & \multirow{2}{*}{$\begin{array}{l}\text { Total } \\
\text { No. of } \\
\text { Spore } \\
\text { Tests }\end{array}$} & \multicolumn{2}{|c|}{ No. Surviving Aftere⿳亠二口 } \\
\hline & & & & $\begin{array}{l}\text { Double } \\
\text { Vacuum }\end{array}$ & $\begin{array}{l}\text { Downward } \\
\text { Displace- } \\
\text { ment }\end{array}$ \\
\hline $\begin{array}{r}6 \\
6 \\
12 \\
12 \\
15 \\
15\end{array}$ & $\begin{array}{l}18 \\
18 \\
18 \\
18 \\
23 \\
23\end{array}$ & $\begin{array}{l}15 \\
15 \\
10 \\
10 \\
15 \\
15\end{array}$ & $\begin{array}{l}30 \\
30 \\
60 \\
60 \\
68 \\
65\end{array}$ & $\frac{0}{\frac{3}{8}}$ & $\frac{\overline{0}}{\frac{7}{19}}$ \\
\hline & & Total & 313 & 11 & 26 \\
\hline
\end{tabular}

the downward displacement method was significantly greater than with the double vacuum method $\left(\chi^{2}=6.3 ; P<0.02\right)$. An incorrect position of the folded towels caused a similar difference (Table III).

\section{Packing and Position of Drums}

Effect of Packing.-The quantities of air trapped inside drums packed tightly, moderately, and loosely were measured. In each experiment a pair of differently packed drums was used. Both methods of air withdrawal were used with each kind of packing.

With 23 towels in each of four drums, the average volume of trapped air was $447 \mathrm{ml}$.; with 18 towels in each of five drums, $189 \mathrm{ml}$.; with nine towels in each of three drums, $60 \mathrm{ml}$. The effect of overpacking on the results of bacteriological tests is also shown in Table II. 

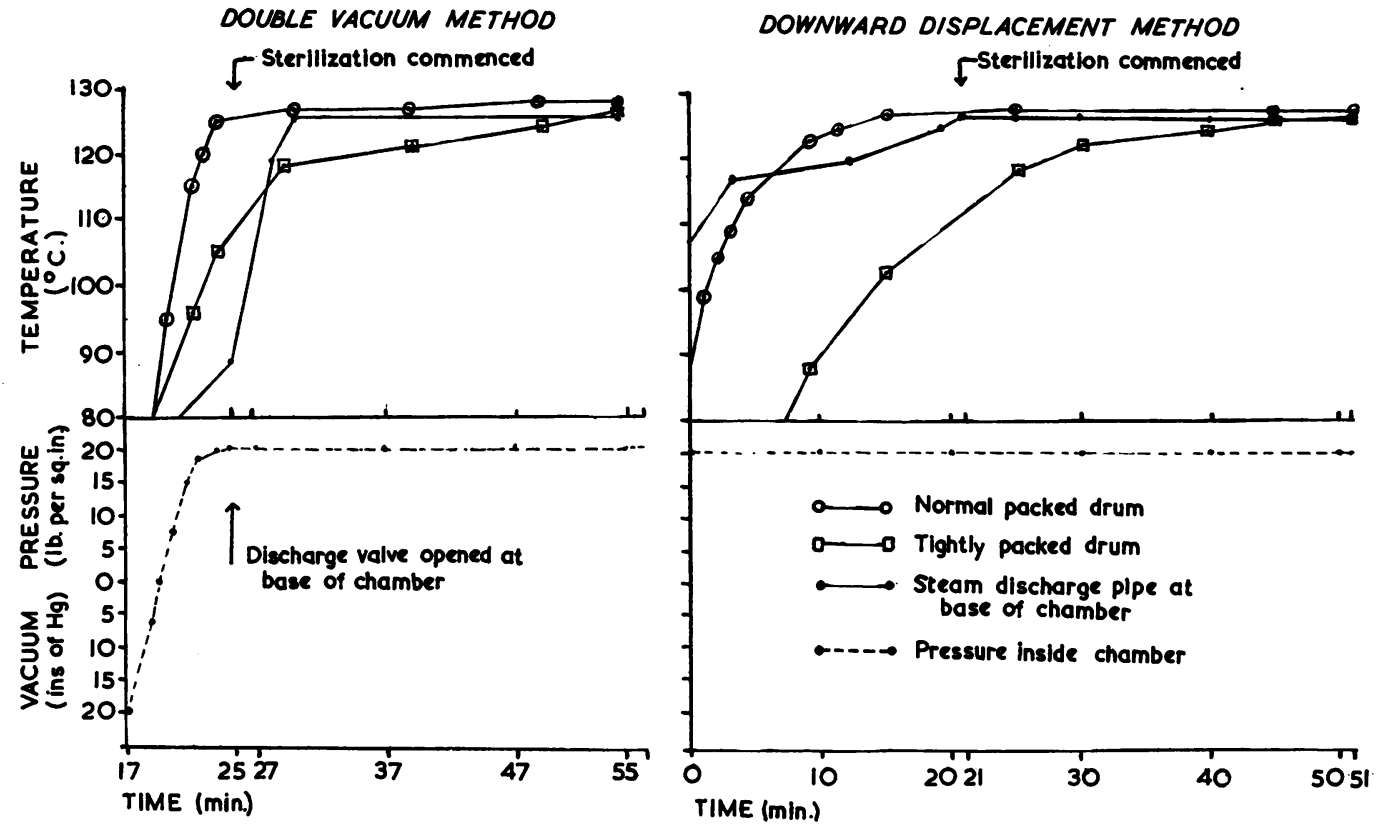

Fig. 2

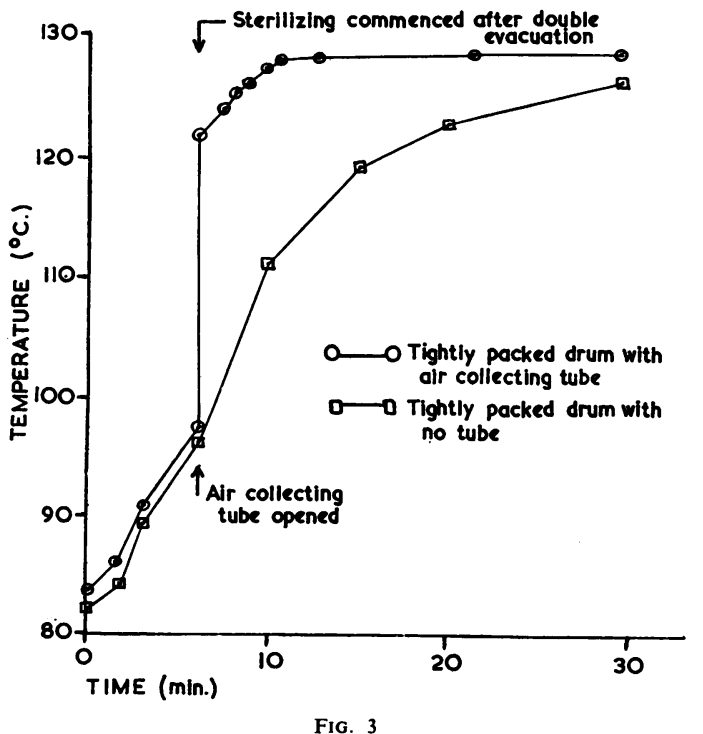

Effect of Position.-It is generally recommended that a drum should be so loaded and placed in the autoclave that folds of fabrics are vertical and that the most dependent part of the drum is perforated so as to allow air to escape the more easily.
Spore tests and chemical tests were placed in groups of loaded drums. Five pairs of tests were placed in each drum, one near the bottom, one near the top, and three at the centre of the contents. All the drums were placed on their sides, so that their under surfaces were perforated, but in some drums the folded towels were horizontal and in some vertical. Two experiments were performed with each of the methods of withdrawing air. Exposure to steam at $20 \mathrm{lb}$./sq. in. for 15 minutes (which left little margin of safety) was sufficient to sterilize all the spore tests in the correctly placed drums, irrespective of the method of withdrawing air. But when towels were horizontal, some spores survived after the downward displacement method, while all were killed after the double vacuum method. Most of the failures were in tests at the centres and bottoms of the drums. The chemical tests behaved similarly. All the results are summarized in Table III. In Table IV the results for horizontally folded towels are arranged to show the difference between drums which had been placed in the top and the bottom of the autoclave chamber.

In the marginal conditions of these experiments, sterilization was best at the top of the autoclave chamber and at the tops of the masses of towels ; and the double vacuum was better than the downward displacement method. 
TABLE III

EFFECTS OF POSITION OF TESTS IN DRUMS, POSITION OF TOWELS, AND METHOD OF AIR WITHDRAWAL ON RESULTS OF SPORE AND CHEMICAL TESTS IN DRUMS EXPOSED TO STEAM AT 20 LB./SQ. IN. FOR 15 MINUTES

\begin{tabular}{|c|c|c|c|c|c|c|c|c|c|c|}
\hline \multicolumn{5}{|c|}{ Method of Removing Air: } & \multicolumn{3}{|c|}{ Double Vacuum } & \multicolumn{3}{|c|}{ Downward Displacement } \\
\hline \multirow{2}{*}{ Test } & \multicolumn{4}{|c|}{ Position of tests in drum .. } & Top & Middle & Bottom & Top & Middle & Bottom \\
\hline & \multicolumn{2}{|c|}{ No. of tests per drum } & .. & . & 1 & 3 & 1 & 1 & 3 & 1 \\
\hline Spore & \multicolumn{3}{|c|}{$\begin{array}{l}6 \text { drums with towels vertical : } \\
\text { No. of survivals } \\
6 \text { drums with towels horizontal : } \\
\text { No. of survivals . . . . }\end{array}$} & $\begin{array}{l}\cdots \\
\ldots\end{array}$ & $\begin{array}{l}0 \\
0\end{array}$ & $\begin{array}{l}0 \\
0\end{array}$ & $\begin{array}{l}0 \\
0\end{array}$ & $\begin{array}{l}0 \\
0\end{array}$ & $\begin{array}{r}0 \\
14\end{array}$ & $\begin{array}{l}0 \\
5\end{array}$ \\
\hline Chemical & $\begin{array}{c}6 \text { drums wi } \\
\text { No. of th } \\
\text {,", ," } \\
\text {,", ", } \\
\text { drums wi } \\
\text { No. of th } \\
\text {,", ,", } \\
,,,,\end{array}$ & $\begin{array}{l}\text { ith towels vertic } \\
\text { tubes coloured } \\
\text {," ,", } \\
\text {,", } \\
\text { ith towels horiz } \\
\text { ubes coloured } \\
\text {," ,", } \\
, ",\end{array}$ & $\begin{array}{l}\text { al: } \\
\text { red } \\
\text { brown } \ldots \\
\text { llive green } \\
\text { green } \\
\text { ontal : } \\
\text { ed } \\
\text { brown } \\
\text { blive green } \\
\text { green } \quad . \\
\end{array}$ & $\begin{array}{l}. \\
. . \\
\ldots \\
\ldots \\
\ldots \\
. .\end{array}$ & $\begin{array}{l}0 \\
0 \\
0 \\
6 \\
0 \\
0 \\
0 \\
6\end{array}$ & $\begin{array}{r}0 \\
0 \\
0 \\
18 \\
\\
0 \\
0 \\
5 \\
13\end{array}$ & $\begin{array}{l}0 \\
0 \\
0 \\
6 \\
0 \\
0 \\
1 \\
0 \\
5\end{array}$ & $\begin{array}{l}0 \\
0 \\
0 \\
6 \\
0 \\
0 \\
0 \\
6\end{array}$ & $\begin{array}{r}0 \\
0 \\
0 \\
18 \\
\\
6 \\
6 \\
12 \\
0 \\
0\end{array}$ & $\begin{array}{l}0 \\
0 \\
0 \\
6 \\
3 \\
3 \\
3 \\
0 \\
0\end{array}$ \\
\hline
\end{tabular}

TABLE IV

RESULTS OF SPORE AND CHEMICAL TESTS IN DRUMS WITH HORIZONTALLY FOLDED TOWELS PLACED AT TOP AND BOTTOM OF AUTOCLAVE CHAMBER

\begin{tabular}{|c|c|c|c|c|c|c|c|c|}
\hline \multirow{2}{*}{$\begin{array}{l}\text { No. of } \\
\text { Drums }\end{array}$} & \multirow{2}{*}{$\begin{array}{l}\text { Position } \\
\text { in } \\
\text { Autoclave } \\
\text { Chamber }\end{array}$} & \multirow{2}{*}{$\begin{array}{c}\text { Method } \\
\text { of Air Removal }\end{array}$} & \multicolumn{2}{|c|}{ Spore Tests } & \multicolumn{4}{|c|}{ Chemical Tests (Final Colour) } \\
\hline & & & Total & $\begin{array}{l}\text { No. } \\
\text { Survived }\end{array}$ & Red & Brown & $\begin{array}{l}\text { Olive } \\
\text { Green }\end{array}$ & Green \\
\hline $\begin{array}{l}2 \\
2 \\
4 \\
4\end{array}$ & $\begin{array}{l}\text { Top } \\
\text { Bottom } \\
\text {,, }\end{array}$ & $\begin{array}{l}\text { Double vacuum } \\
\text { Downward displacement } \\
\text { Double vacuum } \\
\text { Downward displacement }\end{array}$ & $\begin{array}{l}10 \\
10 \\
20 \\
20\end{array}$ & $\begin{array}{r}0 \\
3 \\
0 \\
16\end{array}$ & $\begin{array}{l}0 \\
0 \\
0 \\
9\end{array}$ & $\begin{array}{l}0 \\
8 \\
1 \\
7\end{array}$ & $\begin{array}{l}0 \\
0 \\
5 \\
0\end{array}$ & $\begin{array}{r}10 \\
2 \\
14 \\
4\end{array}$ \\
\hline
\end{tabular}

\section{Comparison of Drums and Packages}

To determine the influence of the container on the trapping of air inside dressings and on the efficiency of sterilization, several groups of 18 folded towels were made up in three ways:

(a) placed in a drum lined with two layers of muslin ;

(b) held together with string and wrapped in two layers of muslin, without a drum;

(c) held together with string, without wrapping.

The trapped air was measured in two packages at a time, one of each kind. Air was sometimes withdrawn by the double vacuum and sometimes by the downward displacement method from each kind of package. The average volume of air obtained from each of 11 drums was $390 \mathrm{ml}$.; from each of 11 muslin-wrapped packages, 179 $\mathrm{ml}$. ; and from each of six unwrapped packages, $92 \mathrm{ml}$.

On four occasions a loaded drum lined with one layer of calico was compared with one lined with two layers of muslin. There was little difference in the amounts of air trapped ; the average quantity with calico was $280 \mathrm{ml}$, and with muslin $210 \mathrm{ml}$.
A number of comparisons were made between the results of spore tests in loaded drums and in $\mathbb{Q}$ calico-wrapped packages of the same shape, size, $\overrightarrow{\vec{A}}$ and content, autoclaved simultaneously. Some- $\frac{1}{3}$ times the double vacuum method was used and sometimes the downward displacement method. The sterilization time and size of load were also varied on different occasions. Altogether, 31 out of 90 spore tests survived in 18 drums, whereas there were no survivals among the 33 tests in seven packages.

\section{Comparison of Chemical and Bacteriological Tests}

That there was close agreement between the results of chemical and spore tests is evident $\bar{N}$ from Table III. The results of all the paired 5

TABLE V

RESULTS OF PAIRED CHEMICAL AND BACTERIOLOGICAL TESTS IN ALL EXPERIMENTS

\begin{tabular}{c|l|c|c}
\hline \multicolumn{2}{c|}{ Chemical Tests } & \multicolumn{2}{|c}{ Spore Tests } \\
\cline { 1 - 3 } & Colour & Sterile & Not Sterile \\
\hline No. & Green & 401 & $3(0.7 \%)$ \\
\hline 404 & Olive green & 12 & $3(20 \%)$ \\
15 & Brown & 20 & $32(61 \%)$ \\
52 & Red & 0 & $18(100 \%)$ \\
18 & Red & & \\
\hline
\end{tabular}


tests done during the course of the work are shown in Table V. Clearly the chemical tests are highly reliable, provided only that a complete colour change is accepted as satisfactory. The makers' instructions on cool storage of the tubes before use must be obeyed.

\section{DISCUSSION}

The efficient withdrawal of air from the autoclave chamber and dressings is essential for satisfactory sterilization. Bowie (1955) investigated the autoclaves in a large number of hospitals and found that many were wrongly designed, installed, or operated, so that removal of air from their chambers must often have been incomplete. But even if air is efficiently removed from the autoclave chamber, significant quantities may be trapped inside dressings, especially if they are enclosed in drums and even more so if the drums are incorrectly loaded or positioned. The quantity of trapped air may be small in relation to the size of the drum, but even a small quantity concentrated at the centre of a mass of dressings may interfere with sterilization. Removal of air with a single partial evacuation by means of a steam ejector has been condemned as unsafe by Walter (1948) and Bowie (1955), who prefer the downward displacement method. With this the authors agree. But the present results show that double evacuation up to $18 \mathrm{in}$. to $20 \mathrm{in}$. $\mathrm{Hg}$, as recommended by some manufacturers, was, with this autoclave, slightly more efficient than downward displacement. The fluctuations in pressure presumably help the steam to mix with and displace residual air from the dressings. However, neither method removes all the air from drums and packages. There is always a residue which presumably escapes gradually into the chamber. For this reason there should be continuous venting from the bottom of the chamber throughout the sterilization period so that residual air may be promptly expelled; and the period should be long enough to give a good margin of safety. Thirty minutes in saturated steam at $20 \mathrm{lb}$./sq. in. should be quite enough for loosely packed and correctly positioned drums and for packages of similar size. Packages trap less air, and if they can be stored satisfactorily after sterilization they are to be preferred to drums. If drums are used, they should be really loosely packed-more loosely than the standard packing used in these experiments - and they should be correctly positioned in the autoclave. Since it is difficult to ensure that every drum conforms to these conditions, the double vacuum method is rather better than the downward displacement method, because it is distinctly more efficient at removing air from overloaded drums and from drums in which gravitation is impeded by horizontally folded contents. But either method, if properly used, is satisfactory. A vacuum method operated by a pump giving a vacuum of $28 \mathrm{in}$. $\mathrm{Hg}$, such as is supplied by some manufacturers, should be still more efficient.

Vacuum methods do not damage materials unless the jacket temperature is improperly high, or, possibly, unless fabrics are in close contact with the jacket wall. This should be prevented by a suitable cage.

A thermometer in the steam discharge port at the bottom of the chamber gives valuable control of the operation of the autoclave, and should be used irrespective of the method of removing air. It must be an accurate instrument, since a small error might conceal serious retention of air if the downward displacement method is being used. For the same reason, if venting from the bottom of the chamber is controlled by a thermostatically operated valve, it must be correctly adjusted. And whether the venting is automatic or hand-controlled, the discharging steam and condensate should be easily visible to the operator. With Savage (1954) the authors prefer to have a continuous escape of steam throughout the sterilization period rather than an intermittent escape controlled by an automatic valve.

Correct operation of the autoclave is not enough for the satisfactory control of sterilization. Check tests should be placed in the centres of drums and packages chosen at random. Highly resistant, non-pathogenic spores, of known thermal resistance, should be used regularly. Many sporing bacilli, including strains found in soil and dust, are easily killed by steam of $100^{\circ} \mathrm{C}$. in five to 10 minutes, and do not provide a severe enough test. The use of B. stearothermophilus (N.C.A. 1518) was suggested by Mr. T. E. Bashford (the Metal Box Company), and it has been found satisfactory. It is also recommended by Perkins (1956). It should be noted that the spores are too resistant for use with gloves, if, as is usual, they are autoclaved at a lower temperature than dressings. Since the result of a bacteriological test is not immediately available, a good chemical test is a useful supplement. Messrs. Browne's colour tubes agreed closely with the authors' bacteriological tests, and with Howie and Timbury (1956) can be regarded as satisfactory. But chemical tests should not be relied on alone. They cannot detect failures due to unsaturated steam.

Good administration should ensure that dressings are never left out of the autoclave in error. 
If an additional check is required, a colour tube may be placed in every package and drum; but if the cost is too high, a cellophane-wrapped tablet containing lactose $75 \%$, starch $24 \%$, and magnesium trisilicate $1 \%$ may be used instead (G. $\mathbf{H}$. Darling, personal communication). The tablets can be supplied already enclosed between cellophane sheets. Disintegration of a tablet by steam shows that it has been in the autoclave, but of course does not prove that sterilization has been satisfactory.

Dressings, once sterilized, should be protected from contamination by unfiltered air in the drying process which follows sterilization (Howie and Timbury, 1956).

Finally, it should be emphasized that freedom from sepsis attributable to contaminated dressings is no proof of satisfactory sterilization. The common organisms of sepsis are very easily killed by heat. Highly resistant pathogenic spores may be only rarely present in dressings, but the method of sterilization must be good enough to kill them with certainty.

\section{SUMMARY}

The efficiency of sterilization of fabrics in an autoclave was assessed under various conditions, by measuring the volumes of residual air trapped in towels, by recording temperatures, and by means of chemical tests and tests with spores of known high resistance.
Bundles of towels wrapped in cloth trapped less air than similar bundles in drums, and were more easily sterilized.

Overloading of drums, and incorrect positions of drums or their contents, all interfered with sterilization.

Air was almost completely removed from the autoclave chamber both by double evacuation, using a steam ejector, and by downward displacement. Neither method removed all the residual air trapped in dressings. Double evacuation was slightly better; its superiority became greater when drums were incorrectly loaded or positioned.

Browne's chemical tests were found to be good indicators of safe sterilization and useful supplements to bacteriological tests.

We thank Mr. P. H. Veysey (hospital engineer), whose generous assistance made this work possible, Messrs. T. E. Bashford, G. H. Darling, and F. L. Mason for technical advice, and Miss M. E. Thompson for help with some experiments.

\section{REFERENCES}

Bowie, J. H. (1955). Pharm. J., 174, 473, 489

Howie, J. W. and Timbury, M.C. (1956), Lancet, 2, 669.

Ministry of Health (1955). Report of the Central Pathology Con mittee of the Ministry of Health on the Ste:ilization of Hospitat Equipment (1955)

Perkins, J. J. (1956). Principles and Methods of Sterilization? Thomas, Springfield, Illinois.

Savage, R. M. (1937). Ouart. J. Pharm., 10, 445.

(1954). J. appl. Bact., 17, 278.

Walter, C. W. (1948). The Aseptic Treatment of Wounds. Macmillan, New York. 